\title{
Introduction to Central America and Mexico: Efforts and Obstacles in Creating Ethical Organizations and an Ethical Economy
}

\author{
Denis Collins \\ Julie Whitaker
}

\section{Central America and Mexico}

Central America and Mexico are important economic and cultural regions. Although plagued by ongoing civil wars, government corruption, shadow economies, and extreme poverty, the region is also rich in indigenous traditions and languages, natural beauty and resources, art and music. Increasingly, it is also the site of global commerce and investment.

The liberalizing trade agreements signed between Mexico/Central American countries and more prosperous countries, like the U.S. and Canada, have facilitated foreign investment and a dramatic increase in commercial imports and exports. Mexico, in fact, now boasts one of the most open economies in the world, with its prime trade partner immediately to its north. After Canada, and China, Mexico is the United States' third largest overall trading partner, and second largest country for exports, with good exchanges reaching a record high of $\$ 368$ billion in $2008 .^{1}$

Denis Collins is a Professor of Management in the School of Business at Edgewood College. He has published numerous articles and books in the area of business ethics and society. His latest book is Essentials of Business Ethics: Creating an Organization of High Integrity and Superior Performance (John Wiley \& Sons, 2009).

Julie Whitaker is an Assistant Professor of Sociology in the Department of Social Science at Edgewood College. She specializes in the sociology of gender and community-based research. In 2006 and 2007, Professor Whitaker lived in east-central Mexico, where she taught community-based research at the University of Veracruz. Her current research focuses on Mexican migration to the U.S.
Mexican/Central American business operations and workers are firmly interwoven into the fabric of the world economy. The 1994 North American Free Trade Agreement (NAFTA) was re-established in 2005 to further expand market opportunities, allowing for "deep integration" of business activity among North American countries. Likewise, Central American Free Trade Agreement (CAFTA), implemented in 2006, reduced barriers to trade of commercial goods and services and investment between the U.S. and most Central American countries. These trade agreements alter not only the rules of conducting business, but also the daily practices and traditions in Latin America.

The presence of transnational companies is becoming the norm in the latest era of economic integration. This is evident in the growing number of mergers between Mexican/Central American, U.S. and Canadian businesses and the rise in foreign manufacturing and retail operations employing Mexican/ Central American laborers and selling products directly to Mexican/Central American consumers. In fact, as a result of more open markets in North America, Walmart is now the largest private employer in Mexico, diversifying its product lines to include grocery chains and banks, and exerting a profound influence on Mexican consumers, suppliers, and local store owners.

With trade and investment integration also comes the potential for integrating cultures and people throughout the Americas. On the southern side, U.S. and Canadian companies have more of a presence in Mexico and Central America, recently having gained the right to purchase land and increasingly retiring as "ex-patriots." On the northern side, the number of 
Latinos working, attending school and raising families in the U.S. has skyrocketed. The Latino population in the U.S. has increased particularly since 1970, with the largest growth occurring during the 1990s, when trade liberalization began. Latinos, foreign and native born, now represent $15 \%$ of the U.S. population, making them the largest ethnic minority group in the U.S. ${ }^{2}$ Viewed from the other side of the Rio Grande, of those born in Mexico, $11 \%$ reside in the U.S. ${ }^{3}$ The political and cultural influence of Latinos in the U.S. is significant, not only in traditional states like California, Arizona, New Mexico, and Texas, but also increasingly in other regions of the U.S. Likewise, the remittances sent by migrants to Latin America, and their cross-national experiences have important effects on them as individuals and their home countries.

The Obama administration has called for renewed and closer relations with Latin America. As the Americas are bound together through business relations and immigration, people in the more affluent countries should understand Latin American culture, history, and economy, and be asking hard questions about the ethics of transnational business operations.

The co-editors of this special edition arrived at their interest in the topic of business ethics in Mexico and Central America from personal experiences.

\section{Denis's interest}

I was born in the Bronx and grew up in a working class suburban New York City community. My interactions with Mexicans and Central Americans were limited. I had never travelled west of Philadelphia prior to my 22nd birthday, so my cultural knowledge was limited to the horrors dramatized in movies such as El Norte and City of God.

Then, during Spring break 2008, I joined a group of Edgewood College students and three professors on a Madison-Arcatao Sister City Project educational immersion. We studied El Salvador's cultural, political, and economic history prior to our arrival. Words and images from books, articles, videos, movies, and Internet searchers did not adequately represent the complexity of the relatively small nation's tragic history.

We stayed in a rather nice middle class San Salvador neighborhood our first few days. Memories include extremely hospitable people living in colorful homes separated from the main street by a brick wall adorned with swirling barbed wire to keep the criminals away. I have experienced many low-income communities in the U.S. where windows and doors are gated and locked to prevent the poor from preying on the poor, but not middle-class homes surrounded by barbed wire barriers. I chatted with the young soldier wearing a machine gun protecting the corner of our block, as well as the security guard carrying a rifle outside the entrance of our local convenient store. Both shared the same story - they were desperate for income and dreamed of relocating to the U.S.

Other vivid memories of the trip include seeing bullet holes in the walls at the University of El Salvador from a confrontation between the military and protesting students, and living several days in rural villages, awakened shortly after midnight by roosters crowing. I previously believed that roosters crowed only with the rising of the sun, nor had I known that they crow all night long. My five member host family, all unemployed, woke up at 5:00 and walked a mile to where the men and boys looked for water and women and girls grinded corn for that day's meals. Families still hid a former European "guerrilla" from the military police, more than 15 years after the Civil War ended.

I also saw a handful of peasants driving SUVs and speaking on cell phones, neither of which I own. They explained that their "wealth" came from a family member who survived riding the tops of trains through Mexico and illegally crossed the border into the promised land of Texas. He was the first family member to successfully complete the journey. When asked where the family obtained the $\$ 5000$ paid to the border-crossing coyote, the father explained that he borrowed the money from an international bank in San Salvador, with his small hut as collateral. According to him, the bank loan officer's decision was a no-brainer: if the son survived, remittances would be sent through the bank; if the son died, the bank would obtain the family's property, which was situated on land some considered to be very valuable.

However, by far the strongest impression of life in El Salvador I brought back to the U.S. was the story of a woman who lived next to my host family. She, along with everyone in Arcatao, ran into the nearby 
mountains during the 1980s Civil War to avoid being slaughtered by government militia looking for Marxist guerrillas and their collaborators. They lived in caves while helicopters hovered overhead and soldiers hunted them down. One day, with the military nearby, her infant child began to cry. What should she do? She suffocated her child so as not to reveal the location of the other 30 people hiding in the cave.

If I had been born to her, rather than my mother, I'd have died by the age of one. If I had been born to peasant parents in Arcatao, rather than a working class parents from the Bronx, would I be a college professor teaching business ethics?

Given the many advantages bestowed upon me by the mere accident of birth parents, I am morally obligated to reach out and help El Salvador's peasant families. One way to achieve that goal is to edit a Journal of Business Ethics special issue about the efforts and obstacles in creating ethical organizations and an ethical economy in Mexico and Central America.

\section{Julie's interest}

I worked in Mexico in 2006 and 2007 as a consultant to the Secretary of Education of Veracruz and as a visiting professor at the University of Veracruz. I had always been interested in Latin America and had visited a couple times previously as a tourist. However, I was able to more deeply experience Mexico the culture, the language, and the people - when I took the plunge and became a more permanent, albeit short-term, resident. I worked, rode the bus, shopped in the markets, attended fiestas, and sent my kids to school for 1 year.

During that year, my work and friendships gave me a window into the lives of the Mexican elites, middle class and poor. Through these personal encounters, I learned a bit about the working lives of Mexicans and how important economic and social class are in daily life. The politicians, successful business people, and ex-patriots that I knew lived in beautiful homes where they employed others and traveled internationally. Others, like many of my middle-class co-workers, employed as teachers and other professionals, lived more modestly, renting small homes or apartments and taking taxis to work.
The poor - mostly working poor - lived handto-mouth.

There was a certain level of indifference to, or at least acceptance of, poverty in Mexico. The poor earned meager wages in the homes of the middle class and elite as housekeepers, gardeners, or chauffeurs. Other poor people barely eked out a living by operating small business enterprises out of their homes or on the streets, laboring in the fields alongside their children or washing clothes in the river. Poverty was so ubiquitous that it almost seemed to go unnoticed.

In Coatepec, the mid-sized pueblo where I lived, some residents lived in gated homes with nice cars and beautiful mountain views from their back patio, while others (a significant number) lived on the outskirts of town in shanties, working long hours to satisfy their basic needs. The latter did so by performing hard physical labor in coffee and sugar plantations, construction, domestic service, or as small vendors of consumable items. Some felt fortunate to find work in the U.S.-owned Coca-Cola or Nestle factories, while others worked the streets at intersections washing windows, selling tortillas, hand-made jewelry, phone cards, or chiclets. Many of the most desperately poor people were children, elderly or disabled. Inequality in Mexico can be extreme and shocking. Income inequality was even more pronounced in Mexico than in the U.S.; thus, the distinction between those enjoying the fruits of global capitalism and those left behind was starker. Although the U.S. has its own brand of extreme inequality, from my outsider's perspective, Mexican class distinctions seemed more obvious and taken-for-granted.

In the face of prevailing conditions, some viewed jobs with U.S.-owned businesses in Mexico with promise, yet I felt uneasy as an American knowing that U.S. companies take advantage of people's desperation by employing them at low wages and treating them poorly. A woman who cleaned house for us twice a week used to be employed as a janitor at the Coca-Cola factory in Coatepec. She told us that she earned more per hour cleaning house for us, and, more importantly, was treated better. While employed at the Coca-Cola bottling plant, if she did not finish all the cleaning during a shift, the management would lock her in the building until it was completed. This made it impossible for her to arrange care for her son and her mother, for whom 
she was responsible. However, like others in Coatepec, there were very few other job options. In fact, I learned just how limited our housekeeper's economic opportunities were when my 8-year-old daughter and I made a return trip to Coatepec after moving back to the States. When we visited her, she told me sadly that, despite much searching, she had not found another job in the 6 months of our absence. When my daughter asked to see the pet iguana we had given her when we left, her son revealed - much to my daughter's terror - that the iguana died and that they had eaten him.

There were other discouraging stories of economic desperation. Nestle and Coca-Cola factories provided jobs for people in my little town, but they were known to pay low wages and drain local water supplies. A local American ex-patriot blogger described not only the low wages and inconsistent scheduling, but also the firing and rehiring of dock workers at the bottling factory, apparently so that the company did not have to pay the Christmas bonuses required by Mexican labor law at the end of the year to uninterrupted year-long employees. ${ }^{4} \mathrm{~A}$ Walmartowned "Superama" grocery in the neighboring city of Xalapa sold - among many other things - U.S. grown vegetables picked (most likely) by underpaid undocumented Mexican workers. This is the same company that all across Mexico employs people to bag groceries as "volunteers" - a labor practice it could never get away with in the U.S. This type of exploitation, in the name of globalization, was all around me in Mexico.

At the same time that these living conditions and labor practices exist in Mexico, U.S. laws and culture label Mexicans as criminals when they sneak over the border in search of something better. Ironically, it was reported that one Coatepec resident employed in the very same U.S.-owned CocaCola and Nestle Coatepec factories, for $\$ 8$ a day, later died alongside a group of rural coffee farmers trying to cross the Arizona desert in 2001 - trying to find something better. ${ }^{5}$ As U.S. and other foreign businesses affect the contours of Mexican life, those of us in privileged countries should feel responsible to understand those effects and attempt to minimize this type of damage.

The 1990s produced more Mexican billionaires than U.S. billionaires, and that wealth has not trickled down to many - especially in Southern
Mexico where I lived. Although there are social movements brewing to create a more just economy, in places like Chiapas and Oaxaca, many just throw up their hands in frustration. The long tradition of a one-party (PRI) government and repressed indigenous peoples leave many Mexicans with a deep sense of fatalism about the entrenched corruption and extreme poverty. It became increasingly understandable to me why someone without much formal education and the right social connections might want to migrate north.

The Mexicans I met were familiar with U.S. culture and geography, from their ubiquitous Spanishdubbed American movies, American consumer goods - as well as familial and personal experiences working in the U.S. Despite their familiarity with the U.S., most Mexicans would much prefer to stay in their beloved Mexico - but are faced with limited economic opportunities, that, for many, have not been made better by trade liberalization.

\section{Efforts and obstacles travelog}

The articles in this special issue have been organized along the path of a Central American migrant traveling north toward the U.S. The story begins with the evolution of economic development efforts in Nicaragua and then visits El Salvador's gold mining industry. Upon entering Mexico, the reader learns about the Mexican government's poverty reduction efforts, experiences a micro credit program in Chiapas, fair trade coffee farmers in Oaxaca, knowledge workers in Cuernavaca, and the evolution of best practices in the maquiladoras along Mexico's northern border. The reader's trip concludes in the U.S., first by crossing the border and exploring migrant deaths in the Arizona desert and then examining border policies and the impact of Central American and Mexico migrations on the U.S. culture. A brief description of each article follows.

Professors Josep Mària and Daniel Arenas analyze efforts to create ethical organizations and an ethical economy in Nicaragua, a nation of 6 million people. The cultural ethos has been shaped by significant shifts in political and economic ideology since the 1970s. After more than 40 years of brutal dictator- 
ship under the U.S. backed Somoza Dynasty, Nicaragua experienced an ethos of revolution informed by Marxism and left wing Christianity during the 1980s, and an ethos of corruption influenced by new pro-capitalist leaders and former Sandinista ministers in the 1990s. The ethos of human development began in 1998, with organizational responses to the devastation of Hurricane Mitch. The researchers describe and evaluate the practices of a microfinance foundation, a federation of cooperatives, and a local branch of an international NGO, all of which represent the ethos of human development.

El Salvador, a nation the size of New Jersey, has been trying to develop its economy through globalization since the 1992 conclusion of a tragic 12 -year civil war. Despite these economic liberalization efforts, poverty remains rampant, with rates over 30\%. Professor Denis Collins examines an on-going conflict among multinational corporations attempting to excavate gold, the pro-capitalist ARENA political party, and left wing social movements generally opposed to multinational corporations (MNCs) and globalization efforts. Pacific Rim Mining, a socially responsive Canadian gold mining MNC, entered the El Salvador market in 2002. Six years later, unable to obtain the necessary excavation permits, Pacific Rim suspended operations. In April 2009, Pacific Rim filed a lawsuit through CAFTA against the government of El Salvador to recover its $\$ 77$ million investment plus damages.

In spite of being one of the most economically developed countries in Latin America, Mexico also suffers from high poverty rates. Approximately $42 \%$ of Mexico's population lives in poverty, of which $14.4 \%$ live in extreme poverty, putting the nation at a distinct competitive disadvantage in the global economy. Professor Oscar Javier Cardenas Rodriguez examines the Mexican government's attempts since the 1950s to ameliorate poverty through two distinct public spending approaches: social programs and economic competitiveness programs. An increase in social spending during the past 15 years has not had a profound effect on reducing poverty. Cardenas argues that federal spending should be reformulated to a more appropriate balance between social programs and economic competitiveness programs.

Micro credit programs that lend money to poor borrowers ignored by banks offer one economic competitiveness approach to alleviating poverty. Professors Gustavo Barboza and Sandra Trejos, after reviewing the literature on poverty and micro credit programs, analyze the performance of ALSOL, a micro credit program in Chiapas, Mexico founded in 1998. ALSOL offers small loans exclusively to impoverished women on the basis of group joint liability. The researchers found that, based on the behavior of 2151 loan participants, the poor are capable of developing successful entrepreneurship ideas, making regular loan repayments, and successfully completing a full lending-borrowing cycle.

Fair trade cooperatives provide another economic competitiveness approach to poverty reduction. Professor Jesus Alvarado examines the development of the fair trade movement both in Mexico and abroad, with particular focus on the experience of UCIRI (Union of Indigenous Communities of the Isthmus Region), an association of small coffee growers in Oaxaca. Since its involvement in the fair trade movement, the yearly income of UCIRI's approximately 3000 members has more than tripled in some cases. UCIRI members earn more for their coffee, eat better, wear better clothes, and have better sanitary features in their houses. However, their financial gains are still not enough to take many UCIRI coffee growers out of poverty.

Mexico is in the process of entering the global knowledge economy. Professor Robert Boutilier conducted semi-structured interviews with eight university-educated knowledge workers from Cuernavaca to explore changes in traditional patriarchal business practices, such as the evolution from nepotism to a meritocracy. The state of Morelos has 18 university campuses, most of them located near the capital-city of Cuernavaca. The interviews, conducted in early 2009 , reveal that knowledge workers consider nepotism to be a socially irresponsible elitist practice. Moreover, family patriarchs have trouble finding competent and interested adult children to fill senior posts in family businesses. Globalization is forcing a change from a traditional patriarchal model to a meritocracy-based model.

The greatest industrial change in Mexico has occurred in the northern regions dominated by maquiladoras. In 2006, maquiladoras accounted for nearly $50 \%$ of Mexico's total exports. Professors Jorge Carrillo and Robert Zarate describe the history of maquiladoras and examine the evolution of best 
practices between 1965 and 2008. Data from surveys conducted in 1990, 2002, and 2006 document a broad diffusion of productive process and industrial organization best practices in six areas: complex activities, capabilities, just-in-time, continuous improvement, environmental performance, and job safety.

Maquiladoras have often been criticized for inappropriate environmental performance. Mexican firms can obtain national certification (Clean Industry) or international certification (ISO 14001) for adopting the best environmental management practices. Professors Ivan Montiel and Bryan Husted examined 1328 facilities, half of which had been environmentally certified, and 217 of which were classified as early adopters. Their research found three variables predict the likelihood of a facility qualifying as early environmental management practice adopter: (1) a connection to an international market, (2) operation in the maquila sector, and (3) linkage to an industry association that offers free resources.

Historically, the lack of economic opportunities in Central America and Mexico, and the availability of economic opportunities in the U.S., has contributed to a large northward migration of people over the approximately 2000 mile border separating the two nations. The 1990s saw a dramatic increase in illegal crossings; of the half million Mexicans who entered the U.S in the past decade, $80-85 \%$ of them were undocumented. The increased fortification of the border in the late 1990s has channeled illegal crossing to inhospitable remote areas, with at least 300 people dying each year in the Arizona desert. Professor Julie Whitaker applies ethical and sociological analysis to determine who should be held culpable for migrant deaths in the Arizona desert: the migrants, humanitarian volunteers, the Mexican government, the U.S. government, and/or U.S. businesses. The greatest culpability is assigned to U.S. trade policies and businesses that benefit from illegal migration.

Approximately 47 million Latinos currently live in the U.S., and nearly $25 \%$ of them are undocumented. In the final article, Professor Ian Davies examines the historical, political, and legislative evolution of U.S. immigration policy, and how antiimmigration discourse in the U.S. is often framed in terms of fear and security. He concludes that government policy-makers should encourage a more tolerant, multicultural society by more humanely integrating Latino immigrants into the nation's social, economic, and political fabric.

That's the end of the road, for now. May you learn a great deal about the economic, political, social, and organizational activities along the path between Nicaragua and the U.S. from this special issue's travel guides. Please join the conversation by extending, modifying, or reacting against, the theoretical assumptions and research findings found in this special issue as we seek to develop a more humane, just, and economically prosperous worldwide community.

\section{Notes}

1 http://www.census.gov/foreign-trade/statistics/high lights/top/top0812yr.html, accessed 7/21/2009.

2 Pew Hispanic Center, 2009, Statistical Portrait of Hispanics in the U.S., 2007, Pew Research Center, Washington D.C.; http://pewhispanic.org/factsheets/ factsheet.php?FactsheetID=46, accessed 7/17/2009.

3 Pew Hispanic Center, 2009, Mexican Immigrants in the U.S., 2008, Pew Research Center, Washington D.C.; http://pewhispanic.org/factsheets/factsheet.php? FactsheetID=47, accessed 7/17/2009.

4 http://www.vivaveracruz.com/blog/?p=778, accessed 7/22/2009.

5 Migration News. 2001, “INS: Border Deaths, Trafficking," http://migration.ucdavis.edu/MN/more.php?id= 2401_0_2_0, accessed 7/16/2009.

Denis Collins School of Business, Edgewood College, Madison, U.S.A. E-mail:dcollins@edgewood.edu

Julie Whitaker Department of Social Science, Edgewood College, Madison, U.S.A. E-mail: jwhitaker@edgewood.edu 